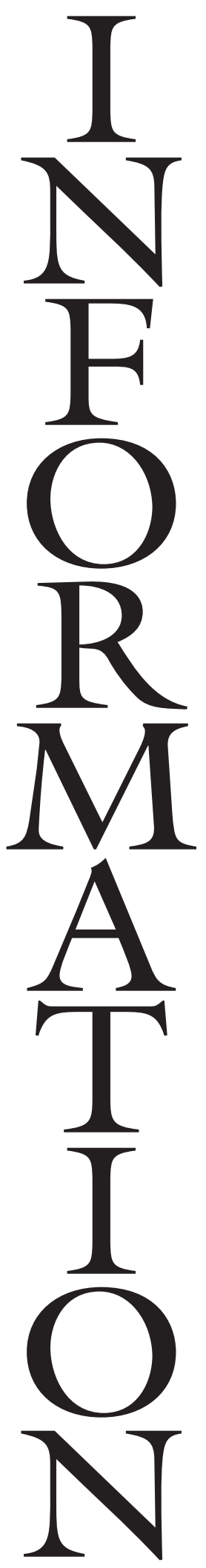

FORENINGEN FOR KøNSFORSKNING

ÅRSBERETNING 2011

BESTYRELSENS SAMMENSETNING 2010-2011

\title{
Forkvinde:
}

Gry Høngsmark Knudsen, mag.art., ph.d.-stipendiat, Institut for Marketing og Management, SDU

\section{Øvrige medlemmer:}

Rebekka Mahler, cand.scient.soc, forskningsbibliotekar, pt. konstitueret biblioteksleder, KVINFO

Mia von Qualen, cand.mag., underviser, Gentofte HF

Diana Højlund Madsen, ph.d., cand.scient.soc., adjunkt, FREIA - Center for Kønsforskning AAU

Michala Hvidt Breengaard, cand.scient.soc., ph.d.-stipendiat, Sociologi, KU

Mia Høwisch Kristensen, cand.mag., AC generalist, Kontor for Inklusion og Mangfoldighed, Københavns kommune

Lotte Bloksgaard, ph.d., cand.scient.soc., adjunkt, FREIA - Center for Kønsforskning, AAU

Katrine Bindesbol Holm Johansen, cand.scient.anth., videnskabelig assistent, Statens Institut for Folkesundhed, SDU

Beate Sløk-Andersen, cand.mag., fuldmægtig, KU

Bine Boldsen, cand.ling.merc., Undervisningsassistent, AU

\section{Suppleanter:}

Helle Poulsen, ph.d., cand.comm., fuldmægtig, Styrelsen for Forskning og Innovation Inge Henningsen, cand.stat., Seniorforsker, $\mathrm{AU}$

\section{Kritiske regnskabslasere:}

Christina Fiig, lektor, Institut for Kultur og Samfund - Europastudier, AU

Lene Mørk Hansen, museumsinspektør, Kvindemuseet 


\section{KRAKA-prisbestyrelsen:}

Forkvinde: Gry Høngsmark Knudsen

Bestyrelsesmedlem: Rebekka Mabler

Tidligere bestyrelsesmedlem: Christina Fiig

Tidligere bestyrelsesmedlem: Yvonne Mørch, lektor, RUC

Eksternt medlem: Niels Ulrik Sørensen, adjunkt, DPU

\section{Administration}

\section{Medlemsadministration}

I 2011 har foreningen haft en stigning i medlemstallet. Foreningen har nu 176 medlemmer, fordelt på 85 studerende, $85 \mathrm{i}$ arbejde, 4 institutioner og 2 gratis medlemskaber.

\section{Økonomi}

2011 gav et overskud på 8.808,54 kr. Foreningens økonomi fortsætter således med at være stabil og vi har nu en formue på 39.059,42 kr., så der også fremover er plads til at dække uforudsete udgifter eller tilbyde årskonferencerne underskudsgaranti.

Desuden har foreningen oprettet en konto med $10.000 \mathrm{kr}$. til festligholdelsen af Foreningens 25-års jubilæum i 2015.

KRAKA-prisen blev i år givet til Signe Arnfred for værket Sexuality and Gender Politics in Mozambique. Rethinking Gender in Africa. Woodbridge: James Currey/Uppsala: The Nordic Africa Institute, 2011.

KRAKA-prisens midler er i år blevet geninvesteret og vi håber at den kommer til at give lidt bedre overskud, i år har Foreningen suppleret prisbeløbet op.

\section{FORSKNINGSPOLITISKE AKTIVITETER}

Foreningen er representeret i forskellige forsknings- og ligestillingspolitiske fora og har også i perioden taget selvstændige initiativer til fremme af en kønsforskningspolitisk dagsorden. I denne periode har vi bl.a. via koordinationsudvalget fortsat arbejdet med at få sat et nationalt kønsforskningsprogram på dagsordenen, hvilket foreløbig kulminerede i formuleringen af FORSK2020. Vi var ikke formel høringspart men fik vores bidrag indsendt via Kvinderådet. Vi har fortsat arbejdet med forskningsprogrammet og vi er med i HORIZON2020, som er formuleringen af EU's strategiske forskningsprogram.

\section{Deltagelse $i$ udvalg $m v$.}

Foreningen er repræsenteret i forskellige udvalg, netværk og fora:

Koordinationens referencegruppe: Foreningen har fortsat sit gode og tætte samarbejde med Koordinationen for Kønsforskning og har tidligere været repræsenteret i referencegruppen. Der er nu nedsat en styregruppe bestående af repræsentanter fra KU. Foreningen følger dog stadig koordinationens virke tæt, bl.a. via koordineringsudvalget.

Konsforskningsmiljøernes koordineringsudvalg: Diverse bestyrelsesmedlemmer deltager i Koordinationsudvalget for Kønsforskning. Dette udvalg består af en række repræsentanter fra de danske kønsforskningsmiljøer, der mødes to gange årligt med henblik på at udveksle erfaringer, diskutere forskningsmæssige og forskningspolitiske initiativer og give øvrige indspark til Koordinatoren.

Kvinderådet: Kvinderådet koordinerer de kvindepolitiske krav og påvirker udviklingen nationalt og internationalt. 46 organisationer er medlemmer. Helle Poulsen har siden 2006 repræsenteret Foreningen i Kvinderådets styrelse, hvor hun foruden de månedlige styrelsesmøder deltager i Kvinderådets internationale arbejde, arbejdet omkring politisk og ledelsesmæssig repræsentation og er tovholder på et udvalg om uddannelse og forskning. Men Helle er trådt ud af Kvinderådets styrelse og Inge Henningsen stillede ved Kvinderådets generalforsamling op til styrelsen og opnåede valg som suppleant. 
Kønsnetvarket/FORDI: Kønsnetværket har været en sammenslutning af de fleste danske u-landsorganisationer og andre organisationer. Det er et fagligt netværk, der har til formål at styrke de danske ulands-NGO'eres arbejde med køn, ligestilling og mainstreaming. Netværket bliver finansieret af Danida og huses af Folkekirkens Nødhjælp. Foreningen har deltaget i netværkets arbejde, da et af formålene er at få et mere kontinuerligt samarbejde mellem NGO'ere og forskere, der arbejder med køn og udvikling. Diana Madsen og Helle Poulsen har deltaget i netværket, og Diana Madsen sidder som suppleant i styregruppen. Kønsnet er pr. 17. april 2012 ændret til netværket FORDI, hvor Mia von Qualen nu deltager for foreningen eftersom både Diana Madsen og Helle Poulsen træder ud af bestyrelsen.

Kvindemuseet $i$ Danmark: Foreningen har været repræsenteret i Kvindemuseets bestyrelse ved Christina Fiig, der tidligere har været medlem af Foreningens bestyrelse. Christina har i årets løb orienteret Foreningens bestyrelse om aktiviteter på Kvindemuseet for at bibeholde den kontakt, der har været tradition for, da Kvindemuseet var repræsenteret i Foreningens bestyrelse.

Mainstreamingsnetvarket: Mainstreamingsnetværket af 2005 består af flere organisationer og enkeltpersoner fra bl.a. fagbevægelse, kvindebevægelse og forskningsverden. Netværkets formål er at fremme kønsmainstreaming som metode og dermed ligestillingen i Danmark. Mia von Qualen repræsenterer foreningen i Mainstreamingsnetværket. Mainstreamingsnetværket holdt møde med Manu Sareen som ny minister på ligestillingsområdet og foreningen var repræsenteret af Mia von Qualen. Mainstreamingsnetværket fik også foretræde i ligestillingsudvalget, hvor Foreningen ligeledes var repræsenteret af Mia von Qualen.

NeMM: Netværk for mænd og maskulinitet har til formål at fremme forskningen i maskulinitetsproblematikker og øge dialogen mel- lem forskerne indadtil og derigennem etablere et dansk forskningsfelt om mænd og maskuliniteter, samt skabe netværk mellem forskere globalt. Desuden søger netværket at højne kendskabet til forskningsområdet i en bredere offentlighed og derigennem øge bevidstheden om problemstillinger, der vedrører mænd og maskuliniteter i forandring anskuet i et mangfoldigheds-, ligestillings- og/ eller frigørelsesperspektiv. Mia Høwisch Kristensen repræsenterer foreningen i NeMM.

Kvartalsmøder $i$ Ligestillingsafdelingen: Foreningen indbydes hvert kvartal til et baggrundsgruppemøde for kvindeorganisationer i Ligestillingsafdelingen. Her fortæller afdelingen om de initiativer, der bliver sat i gang og organisationerne informerer om deres aktiviteter samt kommer med input til afdelingen. Forskellige bestyrelsesmedlemmer har deltaget i disse møder for foreningen.

\section{FORMIDLING/SYNLIGGØRELSE}

\section{Nybedsbrev, web og blog}

Bestyrelsen er begyndt at bruge mulighederne på nettet mere til at informere og inddrage foreningens medlemmer. I år er vi nået til at afprøve nyhedsbrevet, som udkommer 1 gang om måneden og har haft god respons fra medlemmerne.

Bloggen bliver fortsat brugt til at offentliggøre foreningens forskningspolitiske tiltag og debatoplæg, invitere til debat og formidle interessante links, artikler, arrangementer mv. af interesse for kønsforskning.

Foreningen er også på Facebook, hvor der bliver linket til alle nye indlæg fra hjemmesiden.

Desuden har foreningen deltaget i en vedholdende avisdebat om anvendelsen af kvotering på universiteterne.

\section{Vakstlaget}

Foreningen har fortsat sit meget succesfulde 
samarbejde med Kvinfo - Vækstlaget, hvor færdige kandidater og ph.d.'er præsenterer deres forskning og hvor der er tid til at networke over en drink efterfølgende. I efteråret 201 lvar der vakstlagsmaraton med seks forskellige oplæg, der præsenterer nyt fra kønsforskningen. Lars Salomonsson Christensen og Julie Richard Fjeldsted talte om Agdonation, søstersolidaritet og genspredning, mens Mai Therkildsen diverterede med Behårede 'freaks' fra Victoriatiden. Maria Roug pegede på at Fædre har et ben i hver diskursiv lejr, når det drejer sig om barsel. Mia Keinicke kiggede på forvrængede spejlinger af køn og seksualitet i værket 'Ladylike'. Og Bonnie Vittrup undersøgte hvordan man knækker kønskoden i folkeskolen. Endelig præsenterede Rikke Voergård-Olesen Ikke-heteroseksuelle bekendelser på arbejdspladsen.

I foråret 2012 har der været to arrangementer henholdsvis d. 24. februar og 13 . april. I februar drejede Vækstlaget sig om køns-identiteter og - kategorier på spil. Beate Sløk-Andersen diskuterede køn som infrastruktur og Rikke Skyum kiggede på moderskabet som kulturel norm. Endelig undersøgte Stine Frydendahl Larsen hvordan kvindelige migrationsarbejdere forhandler positioner som husarbejde og politisk aktivitet.

I april var overskriften "Unge, rus og seksualitet”. Anna Busk Rasmussen kiggede nærmere Paradise Hotel, mens Sidsel Harder diskuterede, hvordan unge oplever sammenhængen mellem stoffer og seksualitet. Det tredje oplæg lå uden for temaet, idet Helena G. Hansen udforskede debatten om kønskvotering i hhv. Danmark og Storbritannien.

I 2012 er det vores ambition at udbrede vækstlaget til miljøerne uden for København både i Odense og Aalborg/Aarhus.

\section{Kvinder, Køn \&̛ Forskning}

Kvinder, Køn \& Forskning bliver udgivet af en udgivelsesforening og er huset og støttet af Koordinationen for Kønsforskning. Derudover modtager det bevillinger fra Kulturministeriet og Forskningsrådet for Samfund og
Erhverv. Foreningen har en økonomisk aftale med tidsskriftet, således at foreningens medlemmer modtager tidsskriftet.

\section{Åskonferencen}

Foreningens årskonference blev i 2011 afholdt i Aalborg af FREIA, under titlen: Magt og mobilisering. Der er flere blogindlæg på hjemmesiden fra konferencen.

Årets konference blev afholdt på RUC af Center for køn, magt og mangfoldighed d. 11. maj under titlen Tro, håb og kærlighed.

Den fremtidige rækkefølge er således:

2013: København

2014: Århus

2015: Odense

\section{PRISBESTYRELSENS INDSTILLING TIL KRAKA-PRISEN 2012}

\author{
Signe Arnfred: Sexuality and Gender Politics \\ in Mozambique. Rethinking Gender in Africa. \\ Woodbridge: James Currey/Uppsala: The \\ Nordic Africa Institute, 2011
}

$R$ ethinking Gender in Africa honoreres med KRAKA-prisen 2012 for sit unikke bidrag til forskningen i køn, kultur og slægtskab i Afrika. Værket væver overbevisende indsigterne fra 30 års feltarbejde i Mozambique sammen med postkolonial feministisk tænkning i fængslende og originale analyser, som præges af en slående åbenhed overfor genstandsfeltet og en opvakt teoretisk nysgerrighed, der kan inspirere alle områder af kønsforskningen.

Der er tale om et pionerværk, som præsenterer kvinder og kvindeperspektiver i Afrika, der ellers kun har fået begrænset plads i kønsforskningen. Undersøgelserne af mozambikanske kvinders initieringsritualer og deres bidrag til kvindelige fællesskaber åbner en ellers 
lukket verden, hvor kvinder fremstår stærke og kreative. Samtidig giver undersøgelserne anledning til kritiske analyser af koloniale og postkoloniale diskurser, som modsætter sig de forestillinger om kvinder, køn og moderskab, som dyrkes blandt Makhuwa-folket i det nordlige Mozambique. Trods stærke mandeverdener har kvinderne her således deres egne domæner, hvor en særlig kvindelig magt anvendes. Værket udforsker denne magt med inspiration fra afrikanske teoretikere som Oyeronke Oyewumi og Ifi Amadiume samt en række andre postkoloniale feministiske tænkere, hvis teoretiske refleksioner løber som en rød tråd gennem hele værket og skaber originale og tankevækkende veje ind i genstandsfeltet. Arnfred inddrager således et afrikansk teoretisk blik, som muliggør andre fortolkninger af køn, magt og kvindeliv.

Rethinking Gender in Africa er samtidig et yderst personligt værk, hvor læseren indvies i forfatterens relation til genstandsfeltet samt i de motiver og holdninger, som gennem årene har præget hendes tilgang til det. Læseren delagtiggøres i de forskningsmæssige blindgyder og begrænsninger, forfatteren er stødt på undervejs, samt de ændringer i perspektiver og metoder, som det har ført med sig. Det afføder en række tankevækkende refleksioner over forskerpositionen, som løbende er blevet sat på spil og gentænkt. Samtidig er værket karakteriseret ved en udpræget kontinuitet: Problemstillinger og temaer genbesøges og genfortolkes. Der er tale om et livsværk fra en forsker, der har viet en stor del af sit forskerliv til at kvalificere og udvikle forskningen i køn, kultur og slægtskab i Afrika.

Rethinking Gender in Africa består af 14 artikler, som er samlet i tre tematiske blokke, der fokuserer på hhv. mozambikanske kvinder og mænds oplevelse af statslige køns- og ligestillingspolitikker, kvindelige initieringsritualer samt kønsrelationer i matrilinexre samfund i det nordlige Mozambique. Artiklerne, der er skrevet i løbet af en 30-årig periode, rammes ind af en nyskrevet indledning, der ikke blot binder det omfattende materiale sammen, men ligeledes giver et fingerpeg om den lethed, hvormed dette værk bevæger sig gennem forskellige tematikker og niveauer og således fremstår som en ypperlig formidling af dansk kønsforskning.

\author{
Bestyrelsen for KRAKA-prisen \\ og Foreningen for Konsforskning
}

\section{TAKKETALE FOR MODTAGELSE AF KRAKA-PRISEN 2012}

\section{Af Signe Arnfred}

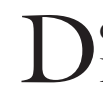

et er en stor og dejlig ære at modtage KRAKA-prisen. Først var det dejligt at blive indstillet til prisen af mine kolleger på RUC - det er skønt at have kolleger, der synes, at man fortjener anerkendelse og hæder og dernæst var det dejligt faktisk at blive udvalgt til at modtage årets KRAKA-pris.

Det værk, der har givet anledning til det hele, er et kønsforskningsbaseret værk, der både er teoretisk, empirisk og på sæt og vis selvbiografisk. Det selvbiografiske kommer sig af, at værket spænder over et forskningsmæssigt og erkendelsesmæssigt forløb på 30 år fra 1980 til 2010. Det hele startede, da mine egne børn var små; jeg har nu børnebørn på samme alder som mine to døtre, da de og jeg og deres far i 1980 flyttede til Mozambique.

Bogens starttidspunkt er 1980, men baggrunden rækker 10 år længere tilbage til starten på den nye kvindebevægelse i Danmark i 1970. Specielt her nu i dagens anledning, hvor jeg står i en dansk kvindeforskningssammenhæng og holder takketale, føles det relevant at inddrage disse forudgående år. Det var mit engagement i denne kvindebevægelse og dens tankegods der for det første var baggrunden for mit ønske om at rejse til Mozambique; for det andet var det fornemmelsen af begrænsningerne i disse tankegange set i forhold til mine oplevelser og erfaringer fra feltarbejde i Mozambique, der nødvendiggjorde 
det gen-tænkningsprojekt, som udgør det teoretiske forløb i den foreliggende bog.

\section{KVIndebeVÆGELSEN I DK}

1970'erne var et opslugende årti. Der var kvindebevægelse alle vegne, på universiteterne, i dagliglivet, kvindekollektiver, kvindehuse, kvindeølejr. Der var nogle paroler, som specielt bed sig fast: 'Det private er politisk', 'Spring kammerat - den gamle verden er efter dig', 'Kvinder er den halve verden', 'Ingen kvindekamp uden klassekamp, ingen klassekamp uden kvindekamp', 'Søstersolidaritet'. Vi havde opdaget styrken ved, at kvinder stod sammen, vi havde opdaget køn som analytisk kategori. Frllesskabet var vigtigt, dels som udgangspunkt for bevidstgørelse og for indsigt i det med, at det private ikke er individuelt, men samfundsskabt og derfor politisk, og dels også for samlet handling: 'Sisterhood is Powerful'. Søstersolidaritet var parolen på lokalt plan og også globalt. For os at se var alle kvinder verden over i samme båd, mandemagten var universel, og det samme var undertrykkelsen af kvinder.

\section{OrganizaÇão da MULHER MOÇAMBICANA}

Det var mit engagement i kvindebevægelsen, der fik mig til Mozambique. Mozambique havde netop gennemført en sejrrig guerillakrig imod den portugisiske kolonimagt, som i 1975 var blevet tvunget til at pakke sammen. Landet var nu ledet af befrielsesbevægelsen Frelimo, og Frelimos leder, Mozambiques præsident Samora Machel, gik aktivt ind for kvindernes befrielse. Han havde selv i 1973 udtalt følgende: "Kvindernes befrielse er en nødvendighed for revolutionen, en garanti for dens fortsættelse og en betingelse for dens sejr". Tænk at arbejde $i$ et land hvor præsidenten kunne tale på denne måde om kvinder!

Jeg fik arbejde i den nationale kvindeorganisation, OMM - Organização da Mulher Moçambicana. Baggrunden for min ansættel- se var, at kvindeorganisationen af partiet havde fået besked om at arrangere en ekstraordinær konference til diskussion af 'kvinders sociale problemer'. I denne forbindelse skulle der indsamles oplysninger fra hele landet om kvindernes situation - familieforhold, xgteskabsformer, sæder og skikke osv. Mozambique er et stort land og meget forskelligt fra syd til nord, men der var på nationalt plan kun højst begrænset viden om disse forhold. I modsætning til de tidligere engelske kolonier, som var blevet grundigt undersøgt på kryds og tværs af britiske antropologer, var Mozambique antropologisk betragtet uudforsket land. Spredte rejseskildringer og rapporter fra missionærer udgjorde ved uafhængigheden det meste af vidensgrundlaget.

OMM's politik var fastsat af partiet Frelimo og havde kvindefrigørelse og kønsligestilling som mål. Der var en stærkt kritisk holdning til sæd og skik, traditioner og ritualer i de gamle bondesamfund. Frelimos politiske projekt var et moderniseringsprojekt, efter sovjetisk model med en stort statslig sektor og omlægning af små familielandbrug til store statsfarme, hvor de tidligere bønder $\mathrm{m} / \mathrm{k}$ skulle blive lønarbejdere. Gammel sæd og skik blev betragtet som dødvægt, der burde afskaffes jo før des bedre. Kvindefrigørelse blev set som en del af moderniteten mens de gamle bondesamfund blev betragtet som kvindeundertrykkende og patriarkalske.

Denne analyse fulgte i store træk den socialistiske kvindeemancipationsteori, som jeg kendte hjemmefra, og som også var en del af grundlaget for vores egen kvindebevægelse: vejen til kvinders befrielse går gennem lønarbejdet og økonomisk uafhængighed af mænd. Kvinder skal ud på arbejdsmarkedet, og samtidig skal arbejdsmarkedet ændres, jf. parolen med ingen kvindekamp uden klassekamp og omvendt.

\section{Vendepunktet i CABo Delgado}

Det var sådan, jeg troede, verden hang sammen. Indtil jeg i 1982 blev sendt til Mozambiques nordligste provins, Cabo Delgado. Be- 
frielseskrigen var startet i Cabo Delgado hvor de 'befriede områder' været størst og flest. Kvinderne havde deltaget aktivt i guerillakrigen, og Frelimo/OMM ville nu gerne vide om og hvordan denne deltagelse havde ændret kvindernes sociale situation.

Rejsen til Cabo Delgado blev et vendepunkt for mit arbejde i Mozambique og for mit kønsforskningsarbejde i det hele taget. Det viste sig nemlig, at disse kvinder i Cabo Delgado, som ganske rigtigt alle sammen havde deltaget i krigen mod portugiserne på lige fod med mænd og som derfor ifølge OMM's teori og forventninger skulle gå i spidsen for Frelimos og OMM's kvindeemancipationsprojekt - det viste sig, at disse politisk bevidste og velformulerede kvinder slet ikke havde lyst til at afskaffe al gammel sæd og skik, og at de af samme grund var meget kritiske over for OMM/Frelimo. Striden handlede ikke mindst om de kvindelige initieringsritualer. Disse ritualer var i OMM's og Frelimos øjne højdepunktet af kvindeundertrykklelse og umyndiggørelse af kvinder men kvinderne i Cabo Delgado insisterede på at blive ved med at praktisere deres ritualer.

Hvordan kunne dette nu hænge sammen? Hvordan kunne disse politisk skarpe og velformulerede kvinder gå ind for sådanne angiveligt kvindeundertrykkende ritualer? Uanset hvordan jeg vendte og drejede mine data kom jeg til samme resultat: at de begreber og den teori, som jeg indtil da havde benyttet mig af, viste sig ganske utilstrækkelig i forhold til at sætte data fra interviews med kvinderne her i Cabo Delgado på begreb.

Det var altså nødvendigt at tænke nyt. Jeg forsøgte med en anden tolkning af initieringsritualerne - at de måske var vigtige elementer til gensidig styrkelse af kvindefællesskabet i den vanskelige situation efter befrielseskrigens ophør, under det nye Frelimo-regime som trods præsidentens fine taler var klart baseret på mændenes magt. Jeg forsøgte også at få OMM til at se sagen på andre måder, at lytte mere til deres egen basis - til kvinderne på landet og i byerne i Mozambique - og mindre til mændene i partiet. Men jeg kom ingen vegne med dét projekt. Heller ikke efter at den landsomfattende kampagne til forberedelse af OMM-konferencen rigtigt kom i gang 1983-1984 med hundredvis af offentlige møder over hele landet til åben diskussion af både initieringsritualer og familie- og xgteskabsformer som brudepris og polygami. Mange af de ting, som jeg havde lagt mærke til i Cabo Delgado, herunder et kvinde/mand magtforhold som ikke kunne beskrives fyldestgørende ud fra en for-forståelse af kvindeundertrykkelse i de såkaldt traditionelle samfund, blev her bekræftet. Men hverken OMM eller partiet ønskede at lytte. Ved selve konferencen mødte Frelimos centralkomité talstærkt op og sørgede for, at kvinderne ikke begyndte at stille spørgsmålstegn ved partiets analyse.

Jeg har senere måttet konstatere, at til trods for de politisk og økonomisk meget forskellige regimer, som i løbet af de seneste 50 år har haft magten i Mozambique - først portugisisk kolonistyre, så Frelimo-socialisme og derpå, fra slutningen af 1980'erne og frem, en neo-liberal økonomisk politik efter Verdensbankens opskrift - og til trods for de ofte drastiske ændringer fra det ene regime til det næste, så har måden at tænke kvindepolitik på ikke ændret sig noget videre. Det hele har været - og er - moderniseringsprojekter; hvad kønsaspekter angår baseret på den samme forforståelse af mandemagt og kvindeundertrykkelse: the universal subordination of women sådan som vi også selv så den i kvindebevægelsens første tid.

Rejsen til Cabo Delgado lærte mig, at kønsrelationer måske ikke altid og overalt hænger sådan sammen.

\section{POST-KOLONIAL AFRIKANSK FEMINISTISK FORSKNING}

Det var først i slutningen af 1990'erne, at jeg fik mulighed for at vende tilbage til det nordlige Mozambique, med henblik på at finde ud af mere om kvindernes liv, og ikke mindst om deres initieringsritualer. Det gik op for mig, at kvinder spiller en ret stor rolle i det nordli- 
ge Mozambique (hvor langt størstedelen af befolkningen tilhører matrilineære grupper); fx er der ofte dobbelt lederskab af en slægtsskabsgruppe eller klan: den mandlige leder er ham, der står frem, når der kommer besøg fra offentlige instanser; han tager sig af det, der almindeligvis opfattes som 'politik'. Den kvindelige leder - som ifølge mine informanter altid er der - tager sig hovedsageligt af andre ting: forbindelserne til de afdøde medlemmer af familien, relationerne i det hele taget til den usynlige verden. Disse relationer er vigtige; dette er tilfældet overalt i Mozambique, også i byerne - men naturligvis i udpræget grad i bondesamfundene på landet også selv om man måske ikke snakker så meget om det, især ikke når der er vesterlændinge til stede.

Det var i denne anden feltarbejdsperiode fra 1998 og frem ikke svært at få data fra kvindelige initieringsritualer i kassen. Jeg var nu på feltarbejde som uafhængig forsker, ikke mere som udsendt af OMM, og desuden var partiet i denne periode mere afslappet i forhold til diverse gamle skikke. Det svære var at finde en indfaldsvinkel til analyse af disse ritualer, som kunne sætte dem på begreb på en passende måde, og også sætte dem ind i en større forståelse af fleksible og mangefacetterede magtforhold mellem mænd og kvinder.

Netop på dette punkt fik jeg meget ud af at læse og diskutere med afrikanske postkoloniale forskere. Jeg fandt her en kritik af vestlig kønsforskningstænkning, som på mange måder understøttede min egen, og som derfor kunne styrke mig i min fornemmelse af at være på rette spor. Disse afrikanske kønsforskere er også inde på kritik af for-forståelser angående altid allerede eksisterende undertrykkelsesforhold mellem mænd og kvinder, ligesom de er kritiske over for overhove- det at tage mand/kvinde to-delingen for givet eller at anse køn for en altid afgørende kategori. Afrikanske samfund er fulde af hierarkier, javel, men ofte er aldershierarkier langt vigtigere end køn. Fra og med kolonisering og mission er køn blevet gjort til en vigtig kategori, lyder det fra disse forskere. Stort set alle tidlige skriftlige kilder om afrikanske samfund stammer fra europxiske rejsende, missionærer og antropologer. Disse har alle været kristne hvide mænd, som har fortolket de afrikanske samfund ud fra deres egen erfaringshorisont, dvs. de har udsat de pågxldende samfundsforhold for en patriarkaliserende fortolkning. Budskabet fra disse post-koloniale forskere er derfor - blandt andet - at det er vigtigt for en forsker også at se kritisk på sig selv - at være i stand til at analysere hvilke mere eller mindre u-erkendte for-forståelser, som man selv som forsker bærer rundt på.

Bogens undertitel: Re-thinking Gender in Africa refererer til den teoretiske rejse, som jeg som forsker har foretaget i løbet af disse 30 år sideløbende med rejser frem og tilbage til Mozambique. Dét, at bogen handler om Mozambique, kan umiddelbart, i en dansk kønsforskningssammenhæng, virke eksotisk og specielt. Men for mig handler den også meget om måder at tænke kønsforskning på. Det post-koloniale blik synliggør en etnocentrisk bias i megen vestlig forskning, inklusiv kønsforskning, som det er vigtigt at være opmærksom på.

Det er kun udefra set, at bogen handler om Afrika. Indefra set handler den om tænkning angående køn. Om måder at tænke køn på, som har relevans også i danske kønsforskningssammenhænge. Jeg er derfor særligt glad for at få netop denne pris, KRAKA-prisen, den danske kønsforsknings pris for netop denne bog. Så TAK, endnu engang. 